\title{
EDITORIAL
}

\section{Iron deficiency and infection: another pathway to explore in critically ill patients?}

\author{
Erik R. Swenson ${ }^{1}$, Raphaël Porcher ${ }^{2}$ and Michaël Piagnerelli ${ }^{3 *}$
}

(c) 2018 Springer-Verlag GmbH Germany, part of Springer Nature and ESICM

Anaemia is a common pathology with a high prevalence and incidence in the general population worldwide and one of the leading causes of years lived with disability and of mortality in myriad chronic medical illnesses [1]. Aetiologies are different depending especially on age and geographical location. In a systematic analysis for the Global Burden of Disease, Kassenbaum et al. [2] reported that iron-deficiency anaemia, haemoglobinopathies and parasitic diseases were the most frequent causes of anaemia worldwide.

Moreover, anaemia is more frequently diagnosed in older patients, the aetiology of which ranges from bone marrow failure syndromes to chronic kidney disease with erythropoietin deficiency and to iron deficiencies due to occult bleeding, inadequate iron intake and chronic inflammatory diseases processes [3, 4].

More than just indispensable for the synthesis of heme, iron, an essential trace element, also modulates host defence, as iron content in macrophages regulates their production of cytokines [5].

Iron is a required cofactor for enzymes that mediate $\mathrm{O}_{2}$-dependent prolyl and asparaginyl hydroxylation of hypoxia-inducible factor $1 \alpha$ (HIF- $1 \alpha)$, which leads to proteasomal degradation of this transcription factor.

Iron depletion in macrophages could therefore mimic the effects of hypoxia, stabilizing HIF- $1 \alpha$ and promoting the transcription and synthesis of interleukin- $1 \beta$ (IL-1 $\beta$ ) and perhaps other cytokines. IL- $1 \beta$ mediates systemic inflammation and activates important host defence mechanisms [6, 7].

*Correspondence: michael.piagnerelli@chu-charleroi.be

${ }^{3}$ Intensive Care, CHU-Charleroi Marie Curie, Experimental Medicine Laboratory, Université Libre de Bruxelles, 6042 Charleroi, Belgium

Full author information is available at the end of the article
These links between low iron concentration and greater inflammation may explain the results observed by Mohus et al. [8] published in the Journal. In a cohort population of 61,852 individuals with a 15-year follow-up, these authors observed an increased risk of bloodstream infections in patients with low iron status. This study has some limitations precluding any firm conclusion. First, one of the primary end points of the study was mortality occurring within 30 days after bloodstream infection. This delay is arbitrary and long, and it does not exclude other causes of death unrelated to infection. Second, concerning the iron status, it was only assessed by iron levels, transferrin saturation and total iron-binding capacity. No measurement of ferritin or hepcidin was available.

Moreover, associations of iron deficiency and anaemia were not possible because of the lack of haemoglobin measurements. The presence of a characteristic hyporegenerative microcytic hypochromic anaemia suggests a profound and chronic iron depletion. The value of haemoglobin could give additional information on the severity of iron deficiency. In this study [8], it is not possible to know if iron deficiency alone is the problem or if it was both that were predictive of bloodstream infections.

Measurements of iron status were made once, but follow-up lasted for 15 years. What happens during this length of time? We do not know whether the patients were supplemented with iron or if the iron status evolved. To answer this question, the authors looked at the iron prescriptions in the general population during the study period and reported that the daily intake of iron was lower than the recommendations, suggesting probably a persistence of iron deficiency in the population studied [8]. This indirect evidence is supported by another report showing that iron deficiency is often underestimated in the general population [9].

Lastly, iron status was measured only once, remotely from bloodstream infection. Looking at iron status at the

\section{6 Springer}




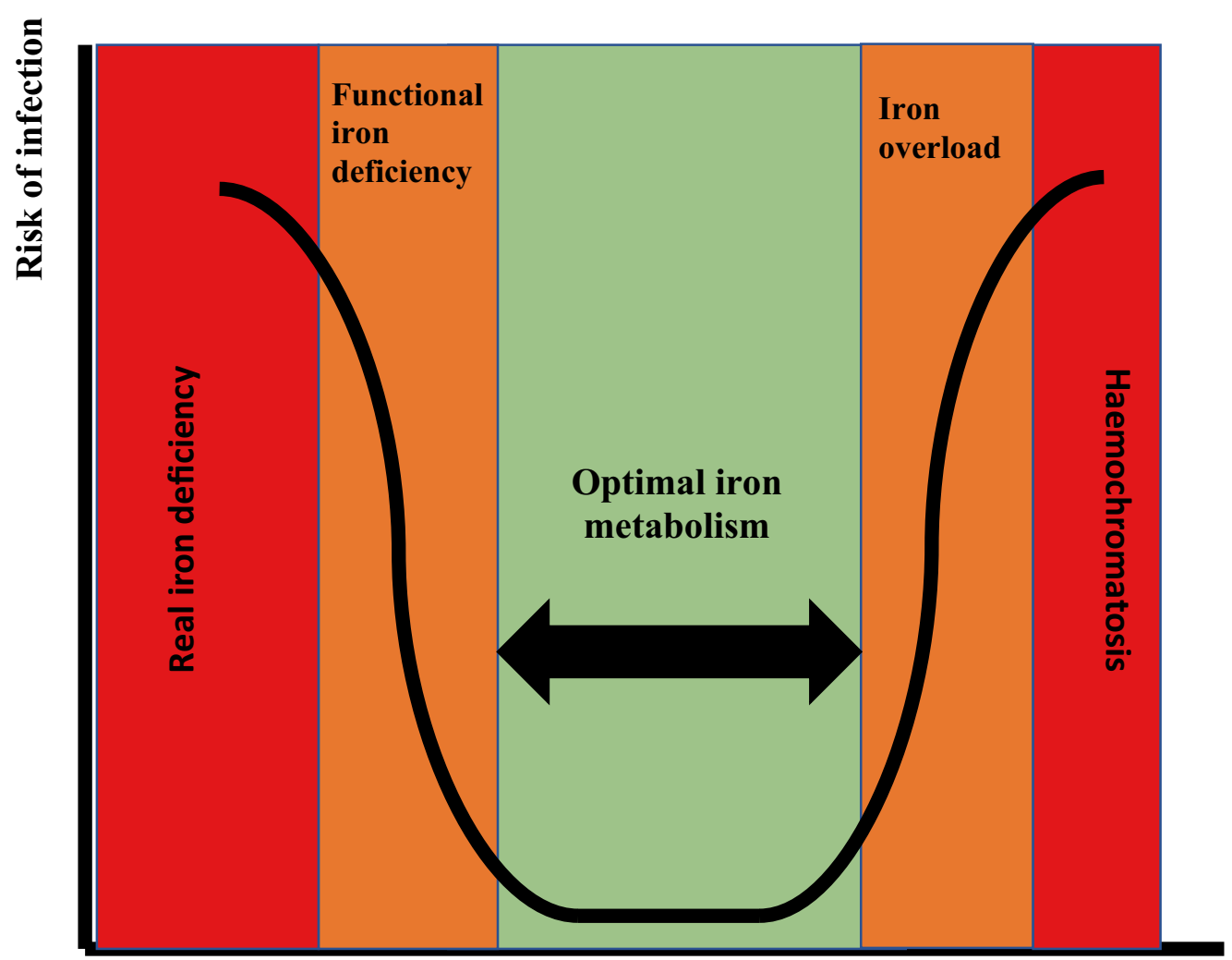

\section{Iron concentration}

Fig. 1 U-shaped relationship between iron concentrations and risks of infection. The red, orange and green colours respectively suggest high, moderate and very few susceptibilities to infections related to iron metabolism. Iron overload includes: red blood cell transfusion and iron supplementation

time of bloodstream infection is likely to be more informative and relevant to studying mortality after infection.

To limit this bias, the authors performed adjustments for comorbidities and excluded patients who developed bloodstream infections during the first 2 years of followup, with chronic illnesses that can lead to inflammatory anaemia (cancer, rheumatic illness or inflammatory bowel disease) and they observed the similar associations, suggesting a possible important role of iron status.

Finally, aetiologies of anaemia observed in critically ill patients are multifactorial and different from the general population included in the study of Mohus et al. [8]. This includes blood loss (surgery, gastrointestinal bleeding and blood sampling) but also decreased erythrocyte production (real or functional iron deficiency due to inflammation, decreased synthesis in erythropoietin) and a decrease of red blood cells lifespan [1, 10]. Since the adoption of a more restrictive transfusion policy nowadays in ICU patients, other treatments for anaemia have been advocated, such as iron administration in those patients found to have iron (real or functional) deficiency.
This topic is under investigation in ICU patients. First, several studies have reported the time course of iron metabolism in relation to inflammation, as observed in critically ill patients $[11,12]$.

Recently, the complex role of hepcidin in inflammation has been better defined: administration of hepcidin or a hepcidin agonist protects against lethal sepsis in mice by clearing non-transferrin-bound iron $[13,14]$ and, in contrast, blocking hepcidin, which limits iron sequestration by the reticuloendothelial system to reverse inflammatory anaemia [15].

Second, clinical trials of iron administration have shown a reduction in the severity of anaemia as would be expected, but also few effects on the risk of infection [16, 17]. If iron overload increases the risk of infection [14], the study of Mohus et al. [8] shows that indices of severe iron deficiency are also associated with an increased risk of bloodstream infection! This suggests a U-shaped relationship between iron status and susceptibility to infection (Fig. 1). What is against us as clinicians and as yet unknown is the optimal dose of intravenous iron 
necessary to stimulate the bone marrow and reduce the requirement for red blood cell transfusion without risks of infection!

Therefore, this study opens the door to in-depth studies exploring the links between iron status and inflammation in ICU patients. It's time to investigate!

\begin{abstract}
Author details
${ }^{1}$ Pulmonary, Critical Care and Sleep Medicine, University of Washington, VA Puget Sound Health Care System, Seattle, WA 98108, USA. ${ }^{2}$ Centre d'Epidémiologie Clinique, Hôtel-Dieu, AP-HP, Centre de Recherche Epidémiologie et Statistique, Inserm U1153, Université Paris Descartes, 75004 Paris, France. ${ }^{3}$ Intensive Care, CHU-Charleroi Marie Curie, Experimental Medicine Laboratory, Université Libre de Bruxelles, 6042 Charleroi, Belgium.
\end{abstract}

\section{Compliance with ethical standards}

\section{Conflicts of interest}

The authors declare that there is no conflict of interest.

Received: 6 September 2018 Accepted: 25 October 2018

Published online: 5 November 2018

\section{References}

1. Hayden SJ, Albert TJ, Watkins TR, Swenson ER (2012) Anemia in critical illness: insights into etiology, consequences, and management. Am J Respir Crit Care Med 185:1049-1057

2. Kassebaum NJ, Jasrasaria R, Naghavi M, Wulf SK, Johns N, Lozano R, Regan M, Weatherall D, Chou DP, Eisele TP, Flaxman SR, Pullan RL, Brooker SJ, Murray CJ (2014) A systematic analysis of global anemia burden from 1990 to 2010. Blood 123:615-624

3. Stauder R, Valer P, Theurl I (2018) Anemia at older age: etiologies, clinical implication, and management. Blood 131:505-514

4. Ferrucci L, Guralnik JM, Bandinelli S, Semba RD, Lauretani F, Corsi A, Ruggerio C, Ershler WB, Longo DL (2007) Types of anaemia in older patients is characterised by low levels of erythropoietin and levels of pro-inflammatory markers. Br J Haematol 136:849-855

5. Ganz T, Nemeth E (2015) Iron homeostasis in host defence and inflammation. Nat Rev Immunol 15:500-510
6. Pagani A, Nai A, Corna G, Bosurgi L, Rovere-Querini P, Camaschella C, Silvestri $L$ (2011) Low hepcidin accounts for the proinflammatory status associated with iron deficiency. Blood 118:736-746

7. Eltzschig HK, Carmeliet P (2011) Hypoxia and inflammation. NEJM 364:656-665

8. Mohus RM, Paulsen J, Gustad L, Askim L, Askim A, Mehl A, DeWan AT, Afset JE, Asvold BO, Solligard E, Damas JK (2018) Association of iron status with the risk of bloodstream infections: results from the prospective population-based HUNT Study in Norway. Intens Care Med 44:1276-1283

9. Fonseca C, Marques F, Robalo Nunes A, Belo A et al (2016) Prevalence of anaemia and iron deficiency in Portugal: the EMPIRE study. Intern Med J 46:470-478

10. Vincent JL, Piagnerelli M (2006) Transfusion in the intensive care unit. Crit Care Med 34:S96-S101

11. Piagnerelli M, Cotton F, Herpain A, Rapotec A, Chatti R, Gulbis B, Vincent $J \mathrm{~L}$ (2013) Time course of iron metabolism in critically ill patients. Acta Clin Belg 68:22-27

12. Boshuizen M, Binnekade JM, Nota B, van de Groen $K$, Cremer OL, Tuinman PR, Horn J, van Bruggen R, Juffermans NP, Molecular Diagnosis and Risk Stratification of Sepsis (MARS) Consortium (2018) Iron metabolism in critically ill patients developing anemia of inflammation: a case control study. Ann Intens Care 8:56

13. Stefanova D, Raychev A, Deville J, Humphries R, Campeau S, Ruchala P, Nemeth E, Ganz T, Bulut Y (2018) Hepcidin protects against lethal Escherichia coli sepsis in mice inoculated with isolates from septic patients. Infect Immun 86:e00253-18

14. Stefanova D, Raychev A, Arezes J, Ruchala P, Gabayan V, Skurnik M, Dillon BJ, Horwitz MA, Ganz T, Bulut Y, Nemeth E (2017) Endogenous hepcidin and its agonist mediate resistance to selected infections by clearing nontransferrin-bound iron. Blood 130:245-257

15. Theurl I, Schroll A, Sonnweber T, Nairz M, Theurl M, Willenbacher W, Eller K, Wolf D, Seifert M, Sun CC, Babitt JL, Hong CC, Menhall T, Gearing P, Lin HY, Weiss G (2011) Pharmacologic inhibition of hepcidin expression reverse anemia of chronic inflammation in rats. Blood 118:4977-4984

16. IRONMAN Investigators, Litton E, Baker S, Erber WN, Farmer S, Ferrier J, French C, Gummer J, Hawkins D, Higgins A, Hofmann A, De Keulenaer B, McMorrow J, Olynyk JK, Richards T, Towler S, Trengove R, Webb S, Australian and New Zealand Intensive Care Society Clinical Trials Group (2016) Intravenous iron or placebo for anaemia in intensive care: the IRONMAN multicenter randomized blind trial: a randomized trial of IV iron in critical illness. Intens Care Med 42:1715-1722

17. Pierraci FM, Stovall RT, Jaouen B, Rodil M, Cappa A, Burlew CC, Holena DN, Maier R, Berry S, Jurkovich J, Moore EE (2014) A multicenter, randomized clinical trial of IV iron supplementation for anemia of traumatic critical illness. Crit Care Med 42:2048-2057 